\title{
CORRESPONDENCE
}

\section{FRANCIS BACON AND CONTINENTAL DRIFT}

It is a favourite opening gambit of lecturers and writers on the subject of continental drift to attribute the first inklings of the concept to Francis Bacon, and the notion that his Novum Organum of 1620 was the first work to point out the "jig-saw" fit of the opposed coasts of Africa and South America is now very firmly entrenched in the literature. The attribution of the idea to Bacon is evidently false, however, and it arises only from a careless reading of the text. The shape of the two continents is mentioned-but only briefly-in Aphorism XXVII of Novum Organum, Lib. II, where Bacon is concerned with analogies and resemblances in nature. He draws a parallel, for example, between the roots of a tree and its branches, and between the beaks of birds, and the teeth of animals. Then, with the same idea in mind, he points out that the Old and New Worlds both taper southwards, and that Africa and South America display a further general similarity in their outlines. Here he does not seem to have been comparing the opposed coasts of the two continents, but rather their corresponding coasts. He in fact offers no discussion of the subject, but it appears he was merely suggesting that a feature such as the "horn" of East Africa may be likened to the "shoulder" of Brazil, or the Gulf of Guinea to the Peru-Chile bight. Various of Bacon's commentators have pointed out that he was not suggesting a "jig-saw" fit of Africa and South America, but geologists-and others-persist in attributing to Bacon the germ of the idea of continental drift.

\section{Geography Department, \\ TRINITY College, Dublin.}

20th May, 1965.

\section{G. L. Davies.}

\section{TONSTEINS}

SIR,-Mining geologists working in the West Midlands coalfields will welcome D. L. Salter's paper on "New Occurrences of Tonsteins in England and Wales" (Geol. Mag., 101, p. 517-9), because of the promise these remarkable thin beds offer for providing numerous stratigraphical marker horizons for which tonsteins have been used for many years in the coalfields of Continental Europe. With this declared interest in tonsteins as stratigraphical marker beds, it is not surprising that mining geologists in the Staffordshire, Shropshire, and Warwickshire coalfields have been concerning themselves with testing the stratigraphical utility of tonsteins at several horizons in the Coal Measures sequences of these coalfields.

Salter's paper raises once again the question of what one may reasonably include under the term tonstein. This term has apparently been accepted by most British coalfield geologists without much reservation though difficulties of definition are alluded to; it usually conjures up a picture of a thin bed having specific stratigraphical value over a wide area. Several workers in this field, notably Scheere (1955, p. 9), have reminded us that the term in its literal sense means neither more nor less than argillaceous rock, but since it has been shown that thin distinctive beds of tonstein in the coalfields of Continental Europe have precise and widespread correlation value, deserving a stratigraphical status little less than that of faunal bands, then clearly the term in its literal sense is unfortunate. That it is a form of kaolinitic mudstone is certain, but so are the majority of seatclays which themselves are noted for their lateral persistence-even greater than the coals which usually overlie them ; since seatclays usually occur in every cyclothem, unless they can be specifically "labelled" their stratigraphical significance is diminished. The same can be said of coals and even marine bands; when they occur too frequently, some special diagnostic feature or association with other beds 
providing a means of specific identification is necessary before they achieve distinctive stratigraphical value.

Most previous authors have implied, if not categorically stated, that tonsteins must possess aggregates of crystalline kaolinite in one or more of several forms; that a band in which kaolinite is present exclusively as a groundmass does not qualify, for if this were the case many argillaceous rocks in the Coal Measures would then achieve the status of a tonstein and this is surely not intended. There would seem to be some significance too in the presence of well-ordered kaolinite. Another important feature emphasized by Scheere $(1958$, p. 310) under the heading "definition ", and one which interests the stratigrapher most, is that tonsteins are of considerable lateral extent.

If one applies the criterion concerning the mode of occurrence of kaolinite in the tonsteins described by Salter from the opencast site near Cannock, the validity of two of them becomes suspect and one needs to have a fuller description to accept them without question as tonsteins; these are the tonsteins referred to as of the dichte type, i.e. the Top Rider and the Cannel tonsteins. The other criterion, which requires considerable lateral extent, apparently and quite understandably has not been applied to the five occurrences recorded by Salter, except that he states (p. 517) that the Higher Bottom Robins Tonstein " is reported to be a constant feature of the Bottom Robins coal over the entire Cannock Chase Coalfield ". One can agree that this coal contains one or more dirt bands, one of which is locally nicknamed, perhaps significantly, Brown George, but the variable positions and number of dirt bands in this coal seam leave one in doubt on present evidence as to whether it is possible to correlate them in detail over a wide area, even supposing their petrographic characters consistently allowed them to be classed as tonstein.

The very interesting results of Moore's (1964) investigation of the Erda Tonstein point to the genesis of kaolinite macro-crystals by microbiological attack of organic matter in a suitable soil environment. The processes which he describes would not necessarily have occurred simultaneously over wide areas ; indeed it is feasible to accept for the present that the conditions necessary to produce the characteristic kaolinite macro-crystals could be found in localized patches in the coal-swamp. The widespread and persistent character of some tonsteins, therefore, depends as much on the mode of formation of the original soil colloid in which the subsequent development of kaolinite macro-crystals took place and in this context the time factor may also be important. Moore (1964, pp. 280-1) points out the various factors influencing the conditions of accumulation of the required soil colloids in coal-swamps, but the environment described seems to indicate that lateral persistence would not be a significant feature except in the special case quoted (p. 281) of wind-borne volcanic material making a widespread contribution.

One is therefore led to question the acceptance of just any tonstein as a continuous and widespread marker bed of precise correlation value.

Up to the present time, only one tonstein has proved to be acceptable as a trustworthy and persistent horizon in the Cannock Chase Coalfield; it is considered to occur at the same stratigraphical horizon as the tonstein described by Earp (1961, p. 163) from the North Staffordshire Coalfield. At many widely scattered points in the Cannock Chase Coalfield it has been found as a sharply defined band about 2 to 5 inches thick, in the dark grey to black fish-bearing mudstones overlying the Wyrley Yard Coal; by reference to marine bands, this occurs between the Kendrick Marine Band above and the Charles (Aegir) Marine Band below. The tonstein's position above the latter marine band varies from about 30 feet in the south of the coalfield to about 80 feet in the north. In the Poplars opencast coal site 1 mile south-east of Cannock, the same tonstein varies from 3 to 4 inches thick, $4 \mathrm{ft} .6$ in. above the roof of the Wyrley Yard Coal.

In hand specimen, this tonstein is cream to pale grey or grey-brown, very fine-grained and brittle, usually closely jointed and exhibiting conchoidal 
fracture ; delicate banding is apparent though the lenticular and irregular nature of this banding suggests plasticity at some stage in its formation ; specimens often disintegrate in the presence of water. In thin section the banded character is clearly seen ; in a groundmass probably composed of kaolinite, abundant roundish aggregates occur in which vermicular rouleaux of kaolinite are conspicuous ; solitary rouleaux of kaolinite also occur. Micro-organisms from this tonstein horizon at Hilton Main Colliery have been figured by Moore (1964A, Pl. 1, figs. 4, 5).

In the Forest of Wyre (Shropshire) Coalfield, a particularly interesting example has been found at Highley Colliery where a mottled red, green, and grey tonstein occurs in red beds of Etruria Marl facies, at a position 95 feet above the correlative of the Charles (Aegir) Marine Band. It is tempting to equate this tonstein horizon with that described above from the Cannock Chase Coalfield, but the southward facies change from grey Coal Measures to the Etruria Marl type of sedimentation presents additional difficulties to detailed correlation with South Staffordshire by conventional means, and in view of the doubts raised in this letter about the stratigraphical utility of tonsteins, and the relatively high incidence of their occurrence revealed by Salter, it would be wrong to rely too heavily on the correlation value of the tonstein itself.

The possibility that tonsteins have some connection with facies changes of dirt bands in coals and with seam splitting is interesting, and Salter's investigation of dirt bands in coal seams may throw some light on this. Our investigation of the stratigraphical utility of several other tonstein horizons in the West Midlands coalfields will continue in the hope that it makes some contribution to the solution of problems associated with tonsteins and their definition.

\section{REFERENCES}

EARP, J. R., 1961. Exploratory boreholes in the North Staffordshire Coalfield. Bull Geol. Surv. G.B., 17, 153-190.

MoORe, L. R., 1964. The Microbiology, Mineralogy, and Genesis of a Tonstein. Proc. Yorks. Geol. Soc., 34, 235-291.

1964A. The Microbiology of some Tonsteins. C.R. V' Congr. Strat. et. Géol. Carbonif., Paris, 1963, 587-592.

SCHEERE, J., 1955. Contribution à l'étude des Tonstein du Terrain houiller belge. Publ. Ass. Etud. Paléont., 19, 1-38.

1958. La pétrologie des tonstein du Houiller belge. Bull. Soc. Belge. Géol. Pal. Hydr., 66, 300-317.

N.C.B., West Midlandos Division,

R. H. HoARE.
HimLeY HaLl,
DUDLEY,
Worcs.

21st June, 1965.

\section{SILURO-DEVONIAN BOUNDARY}

SIR,-It is good to see that at long last a prominent member of the Ludlow Research Group has, albeit somewhat reluctantly, retracted one of the major tenets of the Group's creed. Previously they had all adhered rigidly to the belief that the Ludlow Bone Bed marked the base of the Devonian System. Now it is evident that Dr. Holland (1965) has been convinced by the case presented by Dr. H. Jaeger of Berlin on the graptolites $(1964,1965)$ and by myself on the vertebrates (Tarlo, 1964, 1965), that the Siluro-Devonian boundary should be placed at the base of the Monograptus uniformis Zone, which appears to coincide with the base of the Dittonian (sensu Allen and Tarlo, 1963). This represents a compromise between two extreme views, on the one hand that of the Ludlow Research Group, and on the other that of several workers on the Continent who wish to extend the range of the Silurian to include all the graptolites, even though some of them are now known to occur as high as the Siegenian. General acceptance of Dr. Jaeger's proposal 